\title{
Effect of Ultrasound-Guided Peripheral Nerve Blocks of the Abdominal Wall on Pain Relief After Laparoscopic Cholecystectomy [Corrigendum]
}

\author{
Wu L, Wu L, Sun H, Dong C, Yu J. J Pain Res. \\ 2019;12:1433-1439.
}

On page 1434, "The infusions of remifentanil and propofol were continued at $0.1-0.5 \mu \mathrm{g} \cdot \mathrm{kg}^{-1} \cdot \mathrm{h}^{-1}$ and $3-12 \mu \mathrm{g} \cdot \mathrm{kg}^{-1} \cdot \mathrm{h}^{-1}$, should be "The infusions of remifentanil and propofol were continued at $0.1-0.5 \mu \mathrm{g} \cdot \mathrm{kg}^{-1} \cdot \mathrm{min}^{-1}$ and $3-12 \mathrm{mg} \cdot \mathrm{kg}^{-1} \cdot \mathrm{h}^{-1}$, respectively".
On page 1436, Table 1, 1st column, "Time to unassisted walking (h)" should be "Time to unassisted walking (min)".

Following a review of our data post-publication, we found the incorrect unit of measure was used for Table 1. This correction has no impact on the findings of the study. The authors apologize for this error.

\section{Publish your work in this journal}

The Journal of Pain Research is an international, peer reviewed, open access, online journal that welcomes laboratory and clinical findings in the fields of pain research and the prevention and management of pain. Original research, reviews, symposium reports, hypothesis formation and commentaries are all considered for publication. The manuscript management system is completely online and includes a very quick and fair peer-review system, which is all easy to use. Visit http:// www.dovepress.com/testimonials.php to read real quotes from published authors. 